\title{
Analytic Theology as a Way of Life
}

\section{William Wood \\ Oriel College, Oxford}

\begin{abstract}
Many theologians reject analytic theology because they find it too abstract and spiritually sterile to count as genuine theology. In contrast, I argue that analytic theology may be understood as a spiritual practice. It is an authentic development of a tradition of Christian philosophical theology, which includes Anselm and Aquinas as members, and which treats theology as both theoretical and practical at once.
\end{abstract}

\section{Introduction}

Many conventional theologians remain deeply suspicious of analytic theology. Some worry that "analytic theology" is little more than a brand name, a convenient label adopted by a small group of theologically conservative analytic philosophers of religion who wish to mount a hostile take-over of the theological academy. Others reject analytic philosophy of religion, and assume that it commits us to treating God like a thing in the world-in effect, an idol. ${ }^{1}$ (Presumably analytic theology then inherits the sins of its philosophical forebears.) Still others hold that analytic theology is not sufficiently attentive to the historical and cultural context of its claims. ${ }^{2}$ This essay addresses a different worry about analytic theology: that all

\footnotetext{
${ }^{1}$ John Milbank makes this charge with characteristic bombast. He criticizes "recent manifestations of 'analytic philosophy of religion' in the writings of Richard Swinburne, Thomas V. Morris, et al." for too-sharply separating philosophy from revelation, with the result that their "approaches to these matters tend to be misdescribed in ontotheological terms which treat God as simply 'a supreme being' and the consequent discussions of supposedly Christian theses are, as a result, as worthless as would be the discussions of the belief-systems of an imaginary tribe" $(2009,320)$.

${ }^{2}$ Simon Oliver aptly gets at the heart of this charge in his review of Crisp and Rea (2009): "It is not simply that theologians bemoan analytic philosophy's apparent naivety in the reading of historical texts or that such philosophy frequently imposes concepts, categories or questions which are alien to those texts (think of the way in which Anselm's Proslogion is read through the lens of the ontological argument for God's existence, or, as Coakley points out, the category of 'experience' is used to read texts in mystical theology). Rather, the concern with history is better reflected when one recalls why theologians have been quick to engage with continental philosophy. In this tradition, genealogy is an important part of philosophical method. There are a variety of such genealogical approaches, demonstrated in thinkers as diverse as Nietzsche and Foucault. The key point, however, is simple: concepts have histories. They therefore have genealogies which have to be traced in order that our understanding of those concepts, and the rationalities which formed them, might best be understood.
}

Journal of Analytic Theology, Vol. 2, May 2014

10.12978/jat.2014-1.220812221403a

(C)2014 William Wood • (C) 2014 Journal of Analytic Theology 
genuine theology is in the first instance practical: aimed not at achieving better explanatory theories about God, but at fostering greater love for God and neighbor. Genuine theology, in short, is a praxis, one deeply woven together with a Christian life of prayer, virtue, and participation in the sacraments. ${ }^{3}$ Analytic theology exhibits none of this. The worry, then, is that analytic theology is spiritually sterile and therefore not really a form of genuine theology at all.

Michael Rea raises this worry himself in his introduction to the Analytic Theology volume. He agrees that analytic theology is not a spiritual practice, yet denies that this fact constitutes a genuine objection to it. On his view, theology is a second-order theoretical discipline, and therefore not a source of spiritual nourishment. For spiritual nourishment, we should look to scripture, not theology, and certainly not to academic theology (Crisp and Rea, 2009, 18-19). Rea's response makes sense. It seems unlikely that all genuine theology is practical; nor has this view been the consensus of the Christian tradition. Theoretical tasks like "clarifying, systematizing, and model-building" have always featured in theological discourse.

Rea's response makes sense, but it is unlikely to be dialectically effective. Rightly or wrongly, many theologians associate theorizing and system-building with "idolatrous" metaphysics and ontotheology. They are unlikely to agree that theologians ought to restrict their work to the theoretical tasks delineated by Rea. They are also unlikely to agree that those theoretical tasks have featured quite so prominently in the authentic Christian tradition. Indeed, contemporary work in historical theology has tended to emphasize the spiritual and practical dimensions of even paradigmatically theoretical thinkers like Aquinas. ${ }^{4}$ The trajectory of contemporary theology, then, has been to insist that praxis is central, even when it might initially appear otherwise.

I believe that Rea cedes too much ground to opponents of analytic theology. For there is a sense in which analytic theology does cultivate wisdom, moral improvement, and love for God, and so may be understood as a spiritual practice. Or so I shall argue. My plan is first to clear the ground a bit, by saying just what I think analytic theology is, and just what is at stake in calling it a spiritual practice. I then discuss Anselm and Aquinas, who present two historical examples of theology that is both theoretical and practical in the relevant sense. These historical case studies pave the way for the main argument. It is possible to treat analytic theology as an authentically Christian spiritual practice because certain specific features of analytic argumentation can be regarded as spiritual exercises that cultivate virtue. The task

As such, history is determinative of concepts, or at least indicative of the meaning of concepts" (2010: 466-7).

${ }^{3}$ One finds this vision expressed from many different quarters: from classic liberation theology (Gutiérrez, 1973) to contemporary postmodern theology (Vanhoozer, ed., 2003, 24-5, 43). See also Coakley: "systematic theology without contemplative and ascetic practice comes with the danger of rending itself void; for theology in its proper sense is always implicitly in via as practitional" (2013, 45).

${ }^{4}$ In addition to the works cited in the discussion of Aquinas below, see the second volume of JeanPierre Torrell's study of Aquinas, Thomas Aquinas: Spiritual Master (2003), followed by his volume of essays, Christ and Spirituality in St Thomas Aquinas (2011). 
of the intellectual, Christian or otherwise, analytic theologian or otherwise, is to see things as they are rather than as we want them to be. Thus the intellectual life is also a life of virtue insofar as it requires us to engage in a disciplined and patient search for truth, and to subdue the prideful ego so that we will recognize the truth when we see it.

Before continuing, however, I want to be very clear that I mean to imply no invidious contrasts. I do not argue that analytic theology is more spiritually nourishing than other kinds of theology. I do not mean to suggest that everyone would be better off intellectually-let alone spiritually-if they converted to the one true method of analytic theology. My argument is actually fairly narrow, and is aimed only at the assumption that analytic philosophy of religion, or analytic theology, is especially spiritually sterile. That assumption is false.

\section{What is analytic theology?}

It is helpful to distinguish analytic theology from other related forms of philosophical and theological inquiry. Consider first analytic philosophy of religion. On my understanding, the specific task of analytic philosophy of religion is to use the tools of philosophy to investigate arguments for and against the existence of God, as well as to investigate the properties or attributes that the major monotheistic traditions would ascribe to God: omnipotence, omniscience, omnibenevolence, and so forth. Philosophy of religion, in short, concerns what might be called (non-pejoratively, at least here) "bare theism." In distinction from philosophy of religion, we next have philosophical theology. Philosophical theology, as I understand it, uses the tools of philosophy to investigate the theological claims made by a specific religious tradition. Thus, Christian philosophical theology investigates the meaning, coherence, and truth of specifically Christian doctrines like the trinity or the incarnation.

Where does this leave analytic theology? One might worry that analytic theology is just another name for analytic philosophical theology and not anything new or distinctive. In my view, however, this worry is spurious. It is true that there is no sharp distinction between analytic theology and analytic philosophical theology. Nevertheless, the label "analytic theology" functions as a quick and easy way of letting one know the nature of this particular kind of inquiry: it features certain presuppositions and assumptions but not others; it features a certain kind of writing; it appeals to some intellectual influences and interlocutors but not others; it similarly presupposes a certain set of intellectual villains, and so on. The label "analytic theology" is better than the more venerable label of "philosophical theology" as a shorthand description for this kind of inquiry. It is better because it is more specific. There are many different kinds of intellectual work that can justifiably be called philosophical theology-Kant uses the term, Schleiermacher uses the term, and there are many forms of philosophical theology that have nothing to do with analytic philosophy. The label "analytic theology" describes those forms that do. 


\subsection{Is it really theology?}

As noted above, many theologians question whether analytic theology is really a form of theology at all. Yet any genuine dispute about whether analytic theology is or is not theology presupposes that we already know what counts as theology in the first place. And as all sides would surely agree, just what counts as proper theology is sharply contested. We all have definitions or conceptions that we prefer, but no one is in any position to say that it is just obvious to all right-thinking people what is and is not theology. On some definitions, analytic theology obviously counts as theology. There can be no doubt that analytic theology displays reasoned discourse about God, for example. On other definitions, one must admit that analytic theology falls short. Analytic theology typically does not feature first-order exegesis of scripture; if first-order exegesis is a necessary feature of all genuine theology, then analytic theology is misnamed. Of course, such a strict definition of theology comes with considerable costs: most forms of academic theologycontemporary and scholastic-would similarly fall short. ${ }^{5}$ On still other definitions-something like: elucidating the contents of revelation-it is less than obvious how analytic theology fares, making the matter a fit subject for debate.

The important point for now is that even though many people do disagree that analytic theology properly counts as theology, that fact alone does not leave it in any worse shape than many other kinds of inquiry-ancient and modern-that also go by the name of theology. In short, if one wants to argue on formal, definitional grounds that analytic theology is not really theology, then one's prospects for success are dim. It is hard to make an argument that rules out analytic theology without also ruling out most other academic theology as well.

I would offer a parallel argument as a way of softening the ground for my central claim that analytic theology may be understood as a spiritual practice. When we talk about theology as praxis, are we talking about a direct, first-order practice, like lectio divina, worship, or prayer? Or are we talking about a practice that indirectly contributes to the spiritual life and thereby serves the individual Christian or the wider church in some more remote way? Once again, if we mean a first-order practice, then much of what we would generally regard as good theology falls short. Whatever we think of Karl Barth or Hans urs von Balthasar, for example, their central works are exercises in academic systematic theology. They are not devotional manuals in disguise.

But if we mean a more indirect practice, then this charge is actually a very difficult one to make stick. Who but God himself is in a position to say what is or is not indirectly spiritually valuable to someone somewhere? (Believe it or not, I have met people who sincerely claim that they feel closer to God as a result of reading Richard Swinburne.) The point is that it is a mistake, and furthermore a presumptuous mistake, to assume that analytic philosophical theology cannot in principle be spiritually nourishing. Moreover, given certain widely-held views about God's freedom to offer grace as he chooses, this assumption might even be

${ }^{5}$ By "first-order exegesis of scripture" I do not mean merely that a theologian's work is "grounded in the Bible" in some general sense, but that it takes the specific form of Biblical commentary. 
flatly incoherent. Suppose that God's grace causes your heart to swell with gratitude as you come to believe that the Brower-Rea model of the Trinity at last preserves that once-mysterious doctrine from incoherence. Who am I to insist that such a possibility is absurd? God's love rains down on logicians too, after all.

\section{What is a spiritual practice?}

In a sense, I could rest the case here, but I also want to make a more direct, positive case that analytic theology can be a spiritual practice. I therefore must say more about what I mean by "spiritual practice." The French scholar Pierre Hadot (1995) has argued that much ancient Hellenistic philosophy should be read as a series of spiritual exercises, through which would-be philosophers grow in virtue, and are progressively taught how to live and how to die. According to Hadot, ancient philosophical schools resemble what we would call religious sects much more than they resemble the warring intellectual camps of modern philosophy departments. Schools were judged on the kinds of lives their adherents led as much as on matters of theory. Hadot presents two sets of "Stoic-Platonic" spiritual practices preserved by Philo of Alexandria:

One of these lists, enumerates the following elements: research (zetesis), thorough investigation (skepsis), reading (anagnosis), listening (akroasis), attention (prosoche), self-mastery (enkrateia), and indifference to indifferent things. The other names successively: reading, meditations (meletati), therapies of the passions, remembrance of good things, self-mastery (enkrateia), and the accomplishment of duties (84).

I do not propose to rehearse Hadot's own analysis of these practices, but speaking summarily, we can say that intellectual practices are also spiritual exercises when they: (1) aim at self-improvement or liberation, instead of simply the acquisition of knowledge; (2) discipline the passions, since unchecked passions and immoderate desires are the enemy of both the spiritual life and the life of the mind; (3) help us see the world as it really is, rather than as we imagine or wish it to be; and (4) help us cultivate specific virtues that are at once intellectual and moral, like attention or concentration.

All four of these aims hang together: changing the way we see the world is the first step toward changing the self, but we cannot change the way we see the world as long as we are in thrall to the passions and lack the virtues of attention and concentration. Some of the practices enumerated by Philo seem more direct (meditations, disciplining the passions, training the memory) and others seem more indirect (research, investigation, listening). Others occupy a middle ground between the two (attention and concentration). The overall point is that philosophical practices that look like metaphysical theorizing can also have spiritual effects for those who read and think with the right attitude. In other words, the practice of 
philosophy can be spiritually nourishing, even when it is also aimed at constructing better theories. The purpose of retrieving the ancient sense of "philosophy as a way of life" is to show that philosophical writing can be both theoretical and practical at once.

\section{Christian philosophical theology as a way of life: Anselm and Aquinas}

There is a clear tradition of "philosophical theology as a way of life" in the Christian tradition. Analytic theology is an authentic development of that tradition. In order to set contemporary analytic theology in its historical context, I next examine Anselm of Canterbury and Thomas Aquinas. They furnish two quite different examples of Christian philosophical theology that is broadly analytic and also broadly practical. Their theology is broadly analytic, in that it features deductive, linear arguments. It is broadly practical in that it may also be read as an itinerary for spiritual growth. It is now fashionable for theologians to emphasize the spiritual and practical aspects of the theology of Anselm and Aquinas. On the other hand, most philosophers of religion downplay those aspects or ignore them outright. So this section is also an exercise in bridge-building, aimed at convincing both sides to see the value of a rival tradition of interpretation. Anselm and Aquinas present theoretical arguments that are also embedded in wider Christian spiritual practices, with the result that their theology as a whole is both theoretical and practical. Analytic theology is not a direct imitation of either Anselm or Aquinas, but a further stage of development in the tradition to which both belong. By looking at Anselm and Aquinas, we gain a better sense of what it means to say that philosophical theology as such may be regarded as a spiritual practice, and a better sense of the argumentative bar that I must clear in order to show that analytic theology should be so regarded.

\subsection{Anselm}

Anselm of Canterbury is justifiably regarded as a forerunner of analytic philosophical theology. Contemporary analytic theologians and philosophers of religion draw inspiration from Anselm's perfect being theology, his arguments for the existence of God, and his defense of the necessity of the incarnation. They rarely attend to the literary devices and rhetorical forms he uses in his writing, however. Instead, they typically abstract a series of propositional claims from Anselm's text in order to reconstruct what they take to be his real arguments, and then go on to assess those reconstructions. ${ }^{6}$ This method is almost constitutive of the analytic style of engagement with historical sources, and I have no wish to criticize it. Yet the mere fact that analytic exegetes find it necessary to reconstruct and re-present Anselm's arguments shows that he himself offers something other than linear

${ }^{6}$ See, for example, Leftow 1997. 
arguments available for easy inspection. Rather, Anselm's own texts take the form of mediations, prayers, and dialogues-literary forms reminiscent of the ancient spiritual exercises discussed by Hadot.

Consider, for example, the Proslogion. It certainly contains one or more a priori arguments for the existence of God (Pros 2-4), as well as a decision procedure by which we may derive the divine attributes ("God is whatever it is better to be than not to be" [Pros 5]). At the same time, in its preface, Anselm tells us that he wrote the Proslogion "adopting the role of one who strives to raise his mind to the contemplation of God" and describes the often-frustrating process by which he arrived at its central argument as a spiritual struggle that culminates in a joyful spark of insight.7 And, of course, chapter one (entitled "A rousing of the mind to the contemplation of God") is a direct address to God that includes a long meditation on divine hiddenness and the noetic effects of the Fall. Even chapters two and three, which contain the ontological argument, are directly addressed to God. They are, in other words, prayers.

Because it takes the form of an extended prayer, the Proslogion is also implicitly an extended dialogue with God. Some of Anselm's other great works explicitly take the form of dialogues. Hadot has argued that ancient philosophical dialogues are actually intended as spiritual exercises, in which the reader is meant to mimic the student's journey from ignorance to insight (89-93). Marilyn McCord Adams finds a similar motivation in Anselm's dialogues: "The reader is meant, not merely to pass his/her eyes over the text, but actively to meditate the Monologion, to pray the Proslogion, to identify in the dialogue with first one speaker and then the other" (2004, 41-2).

Some readers have so emphasized the prayerful and meditative aspects of the Proslogion that they have gone on to deny that Anselm makes any properly philosophical arguments at all in that text. On this reading, Anselm writes within the context of faith, for an audience of believing Christians, and so cannot be trying to prove with philosophical arguments that the object of his faith is real or has a particular character. Only within the context of faith is it possible to understand the all-important phrase "that than which no greater can be conceived," a phrase that functions more like a divine name revealed by God than like the premise in a philosophical argument. The fact that the "argument" of the Proslogion takes the form of an extended meditation interspersed with direct prayers to God only seems to strengthen this interpretation. ${ }^{8}$

If this interpretation of Anselm is correct, it would furnish valuable ammunition to those who would sharply separate theoretical arguments from

\footnotetext{
7 "Sometimes I thought I could already grasp what I was looking for, and sometimes it escaped my mind completely. Finally, I gave up hope. I decided to stop looking for something impossible to find. But when I tried to stifle that thought altogether... it began to hound me more and more, although I resisted and fought against it. Then one day, when my violent struggle against its hounding had worn me down, the thing I had despaired of finding presented itself in the very clash of my thoughts, so that I eagerly embraced the thought I had been taking such pain to drive away" (Williams, trans., $2007,75)$.

${ }^{8}$ The source of this line of interpretation is Barth 1960.
} 
practical spiritual exercises. In my view, however, this interpretation is untenable. We do not need to suppose that Anselm is holding in suspension his own belief in God or implying that Christian faith requires a conclusive proof that God exists. Similarly, we can also grant that the "fool" addressed by Anselm in Proslogion 2-4 is not a modern atheist or a skeptic who sharply opposes faith and reason. One can grant all this and more and nevertheless hold that Anselm offers the argument in Proslogion 2-4 as a proof that God exists, and that he further offers many additional philosophical, theoretical arguments in the Proslogion and elsewhere.

Anselm offers an a priori argument that God exists using premises that (he believes) any rational person ought to accept, and he also sets this argument in the context of an extended meditation designed to elevate the mind toward the contemplation of God. As McCord Adams recognizes, the Proslogion is meant to do more than communicate propositional truths. It is meant to help reorient the wills of its readers, and help bring about affective and volitional change in them. In this sense, its text resembles a spiritual exercise, like those discussed by Hadot. By virtue of reading Anselm's argument and identifying with Anselm's desire to understand the God in whom he believes, the reader is step-by-step led closer to that very same God.

\subsection{Aquinas}

When we turn from Anselm to Aquinas, we are immediately struck by a clear difference in the style of writing and method of arguing they each employ. ${ }^{9}$ Aquinas does not write dialogues or meditations; nor does he pepper his writings with prayers and exhortations. He treats theology-sacra doctrina-as a deductive Aristotelian science, and explicitly argues that it is more theoretical than practical (ST 1.1.1, 1.1.4).10 To be sure, a large percentage of his corpus is composed of commentaries on authoritative texts, especially the Bible. As Hadot recognizes, the commentary is a venerable genre associated with ancient spiritual practices. And we must note that Aquinas himself explicitly distinguishes sacra doctrina from philosophy, understood as metaphysics (ST 1.1.1, 1.1.8). Yet the science of sacra doctrina employs philosophical reasoning, and its arguments are meant to persuade us to assent to various propositional truth claims. Even Aquinas's Biblical commentaries offer controlled exercises in theoretical argument rather than the digressive, allegorical interpretations of, say, Origen or Bernard of Clairvaux. It is not an accident, and not without reason, that contemporary analytic theologians look to Aquinas as a forerunner. Yet Aquinas also regards theology as a spiritual practice. He can therefore serve as a forerunner of analytic theology in this respect as well, by showing us how theoretical reasoning can also serve the life of Christian virtue.

It is true that Aquinas does not write theology in the classic genres of prayer, meditation or pedagogical dialogue - the very genres that we most associate with

\footnotetext{
${ }^{9}$ My interpretation in this section is guided especially by Jordan 2006, Candler 2004, Hankey 2003, Marshall, 2005.

${ }^{10}$ ST = Summa Theologiae.
} 
philosophy or theology as a practically-oriented "way of life." Yet the genre in which he does write, the disputed question, is very much a kind of implicit dialogue. Indeed, the written questio purports to summarize an earlier, oral, public disputation, in which students and masters presented the best arguments for and against the question at issue. ${ }^{11}$ The written questio does not offer the constant backand-forth between student and teacher that characterizes an Anselmian pedagogical dialogue. But it does formally and explicitly introduce rival voices and arguments, and thereby encourage the reader to "learn by doing," as he finds himself entertaining and critiquing first one set of arguments, then another, before the question is resolved. When the student reads his teacher's words, he learns to think as his teacher thinks. The text of a disputed question does more than commend the specific propositions that Aquinas himself endorses. Reading a disputed question teaches us to imitate the way Aquinas thinks and reasons about God, the ultimate object of contemplation. In this sense, the disputed question presents an authentic development of the earlier Anselmian spiritual practice of writing and reading Christian pedagogical dialogues. The disputed question is not a dialogue, but it does serve a similar pedagogical function: it trains the mind in the techniques of rigorous thinking about God.

In its micro-structure, each individual article of Aquinas's capstone work, the Summa Theologiae, is a miniature disputation that also presents an abbreviated pedagogical exercise for its reader. When one reads an article of the Summa, one first encounters a series of objections, attributed to great teachers of the past. The reader thereby finds himself immediately situated amid an ongoing debate among rival authorities that stretches back to antiquity. The sed contra ("on the other hand") presents a single sharp and equally authoritative alternative view. To consider carefully both the objections and the sed contra requires mental flexibility and a holistic vision of the question at hand. Similarly, only after the reader has grasped the truth-as his teacher sees it - in the responsio (response) can he return to the original objections and understand how they have gone wrong. The reader learns to grasp all sides of an issue while he considers Aquinas's own argument, because Aquinas's argument developed in dialogue with those same alternative positions. The further implication is that Aquinas's own position will be challenged, perhaps by the very student reading his text, and will thus become fodder for future disputations, as the ongoing debate continues.

Accordingly, each article of the Summa trains its readers in the virtue of humility. The objections testify to the fact that even great authorities can err, which reminds the reader that he too can err. The objections and replies together require the reader to consider rival positions carefully and respectfully before dismissing them. Even Aquinas himself, the master, positions himself less as a decisive and infallible guide to the truth than as one inquirer among others, stretching backward and forward through time. Among modern thinkers, one sometimes encounters the claim that there is something inherently prideful about asserting propositional truth claims in theology, and that to do so somehow reduces God to human categories of

${ }^{11}$ For a brief account of the nature of the medieval disputation see Brian Davies' introduction to Aquinas's De malo (On Evil; 2003, 9). 
thought. The Summa shows that this charge is false. To reason well about God presupposes the virtue of intellectual humility, but intellectual humility does not require that we abandon assertion or argument altogether.

In its macro-structure, the Summa can be read as a spiritual itinerary, as we follow the trajectory of Aquinas's own reasoning about God. We progressively learn to understand God as metaphysical first cause, Trinity, creator, and governor of the world (in Part One); then we consider the nature of virtue and the happy life (in Part Two), before Aquinas finally leads us to Christ and the sacraments (in Part Three). Aquinas deliberately chose to treat his topics in this order, of course; it is also wellknown that his chosen order was innovative (Jordan 2004, chap. 6). He wrote primarily for an audience of Dominican preachers, and-once again-he meant for the specific progression of articles and questions in the Summa to teach them how to think about each of the topics he treats, and not just what to think about those topics. Aquinas's deliberately-chosen order has a pedagogical point: if we want to think properly about how to act, we must first learn to see our actions in a wider theological context. As we read through the Summa in order, we are trained to see that all questions, even the most seemingly practical, point forward, toward God as our final end, and backward, to God as our ultimate origin.

The Summa habituates its readers into a tradition of inquiry, a tradition that is also salvific because its object is God. Theology always has a salvific purpose, according to Aquinas. Reasoning about God is valuable because it prepares us for the beatific vision, the final goal of human life, and the fulfillment of our rational and intellectual capacities (ST 1.12.1). In other words, when God grants us the beatific vision, he also perfects the very same intellectual faculties we use when we practice sacra doctrina. Theology is a spiritual practice for Aquinas both because its goal is union with God and because its techniques are a creaturely way of seeking that final perfection. When we reason about God, we seek the beatific vision.

Aquinas, no less than Anselm, belongs squarely in the tradition of Christian philosophical theology as a spiritual practice. That tradition develops and changes in the intervening centuries, to be sure. The scholastic disputed question is like a dialogue, but it is not a dialogue. The Summa can be read as a meditative spiritual itinerary but this interpretation is far from obvious on its face. Still, in the Summa and elsewhere, Aquinas means to commend specific techniques of reasoning about God, in addition to arguments and truth claims. To use those techniques successfully, the inquirer must already have reached an appropriate level of intellectual and moral virtue; moreover, those same techniques also serve to foster intellectual and moral virtues in the inquirer, especially the virtue of humility.

I should now say a word about a distinction that I have to this point intentionally left vague. There is a difference between doing and reading philosophy or theology; that is, there is a difference between thinking and reasoning for oneself, versus reading the work of another. Perhaps it makes sense to say that the former is a spiritual practice, but the latter is not. It is not hard to imagine that Anselm and Aquinas found themselves drawing closer to God as they carefully and prayerfully ruminated and wrote. When we imitate them, when we actually do what they did, it makes sense to say that we also engage in their spiritual practices. On 
the other hand, when we merely read the derivative product of their practices, perhaps we do not imitate them, and do not engage in any spiritual practice at all.

This distinction between doing and reading is real, but it is not absolute. Certainly, it is possible to read any text whatsoever, however explicitly meditative, without spiritual insight or profit. The mere act of reading does not summon up the presence of God. There are no magic spells. On the other hand, as discussed above, when we read even a very technical, theoretical text in the right spirit, the distinction between doing and reading starts to blur. When we read an author's words in the right spirit, we do imitate him, in a sense, because we learn to think as he thinks and see as he sees. Reading becomes doing. When a theologian intends for his text to be read in such a way as to draw his readers closer to God, that theologian may be said to write a spiritual exercise explicitly. But it is also possible that an author might write a spiritual exercise unintentionally: who can say, after all, just which texts will lead readers closer to God?

I have argued that both Anselm and Aquinas did intend for their theology to be read as spiritual exercises, but in fact, that claim is a stronger one than I actually need. It would suffice to say that their texts can be read as spiritual exercises, whether or not they intended them as such. Furthermore, even if it were the case that the intellectual practices of Anselm and Aquinas were spiritually fruitful only in the first, "doing," sense, and utterly sterile in the second, "reading," sense, they would still furnish examples of the practices of Christian philosophical theology as a "way of life" in Hadot's terms.

\section{Analytic theology as a way of life}

I return now to the central argument. I do not claim that analytic philosophical theologians typically intend that their work be read as spiritual exercises. On the other hand, reading analytic theology might well be spiritually fruitful for its readers, when they approach it in the right way. (At least, it would be very difficult to argue that this is not possible even in principle.) It may also be the case that doing analytic theology can be a spiritual practice, even if reading it is not. It is the former option, actually doing analytic theology, that I pursue here, though much of what I have to say also applies, mutatis mutandis, to the latter. The explicit goal of any piece of analytic writing is to present the truth as the author sees it. This single-minded focus on truth, when combined with the specific techniques of analytic philosophical argument, allows analytic theology to become a spiritual practice. It is an authentic development of the earlier tradition of Anselm and Aquinas.

For a Christian, the spiritual warrant for analytic philosophy or analytic theology is derived from the more general spiritual warrant for inquiry as such. Intellectual inquiry as such presupposes a certain level of virtue and it is always, at least implicitly, oriented toward God as the cause and final end of all things. As Christians, we believe that God created us as intellectual creatures, with an innate desire to know that is itself essentially good and healthy, even though it can be 
corrupted. Moreover, the innate desire to know is nothing other than a desire for truth, and in order to desire the truth, we must first love the truth. Indeed, in order to seek the truth in earnest, we must love the truth more than we love the self. We must subordinate our other desires, including our desire for intellectual glory, to the desire for truth. We must let the desire to be right displace the desire to seem right, because the desire to seem right without being right is merely the intellectual version of libido dominandi, the will-to-dominate.

Some might go still further and embrace the ancient and medieval claim that the desire for truth is the desire for God because God is truth itself. ${ }^{12}$ On this understanding, when we seek the truth, we also, by that very fact, seek God. Even if we are not prepared to go that far, we may still say that when we seek the truth, we imitate God, who knows all truths. Seeking the truth is a way of conforming our desires to God's plan for us as intellectual creatures: God wants us to know reality as it is, to know ourselves as we are, and, insofar as it is possible, to know God as he is, and not just as we wish him to be. Insofar as inquiry as such features the patient, disciplined pursuit of truth, it is an attempt to see the world as it really is, to live in the Real, and thereby to depart from the shadow land of illusions and fantasies. To seek the truth, in any form, is implicitly to seek God-surely the very essence of any spiritual practice.

From the point of view of the central argument, this is already a useful result. As I noted above, many opponents of analytic philosophy of religion treat it as a form of inquiry that is almost uniquely spiritually sterile. Yet few would deny that analytic philosophy features an almost relentless focus on assessing truth-claims. This result is important in itself, because it makes the playing field more friendly. Analytic philosophical theology inherits the moral worth of inquiry as such, because it is a way of seeking and loving the truth.

At this point, one might object that much of what I have said so far would apply equally to any form of inquiry-whether the "disciplined" study of history, biology, or whatnot. I agree. My aim so far has been merely to establish that analytic theology is not on worse footing than other forms of inquiry. In fact, however, a Christian can hold that analytic theology is actually on better footing, because it inherits not just the virtues of inquiry generally, but of theology specifically. Analytic theology features the disciplined pursuit of truth that is common to all sincere inquiry, but as theology, it is actually a higher form of inquiry because it has a higher object. Analytic theology-like all good theology-features the disciplined pursuit of truth about matters divine: about God, Christ, and salvation. The general pursuit of truth, itself inherently virtuous, is made more virtuous in analytic theology because of its subject matter: God, God's plan for us, the content of the creeds, the meaning and coherence of revelation, and so forth.

Much like the theology of Aquinas, analytic theology is both directly theoretical, in that it is explicitly concerned with presenting and defending propositional truth claims, but also indirectly practical, because it can also have practical (possibly even salvific) effects. I admit that this claim seems dubious at first blush. One thinks of the shopworn criticism that analytic philosophy, and

${ }^{12}$ For a study of this claim in the thought of Aquinas, see Wood 2013. 
therefore analytic theology, is no more than "logic chopping." On this critique, analytic inquiry might feature the "pursuit of truth," in some minimal sense, akin to mindlessly doing rote arithmetic problems, but it could not be an authentic spiritual practice in Hadot's sense.

Yet the old Augustinian maxim holds here too: knowledge of God and knowledge of self are mutually entailing, and both have implications for how we should live. ${ }^{13}$ Suppose we agree with Aquinas that the contemplation of God is the purpose of human life, and that theoretical reasoning about God can train the intellect to receive the beatific vision. On what basis would we grant this claim for Aquinas, but refuse to grant a similar claim for contemporary analytic theologians? Like Aquinas, analytic theologians use the best philosophical tools to reason about the central claims of the Christian faith. Like Aquinas, the analytic theologian can rightly insist that reasoning well about God is a way of drawing closer to God. By elucidating the contents of revelation, removing objections to Christian belief, and offering possible models of coherence for disputed Christian claims, analytic theologians pursue a theoretical task that is also indirectly practical. We must be guided by the truth about God in order to understand how to live rightly. Analytic theology is a tool that can help us to be good people and to live good lives (compare Swinburne 2005, 33).

So far I have argued that analytic theology inherits the spiritual worth of inquiry as such and of theology in particular. But some specific features of analytic argumentation are especially conducive to the life of virtue. I now wish to identify four such features: cultivating attention, argumentative transparency, imaginative identification with opponents, and passively waiting for insight. All four are ordinary philosophical practices, but they can also have the effect of fostering the virtue of humility and of cultivating a desire for truth, which in the Christian tradition may be understood as a desire for God.

\subsection{Attention}

Consider first the concentrated attention required to read, understand, and develop very technical analytic arguments. The French mystic Simone Weil holds that attention can be an implicit form of Christian prayer because it requires one to detach oneself from one's goals and biases in order to be fully receptive to the objects of our attention. She specifically describes the effort of working out a difficult proof in geometry as a kind of prayer, a way of worshipping God, the source of truth (Weil, 1951, 105-116). Hadot makes a similar point about Stoic spiritual exercises. He discusses "reading, listening, research, and investigation" as spiritual exercises, and he similarly presents speculative metaphysics as a spiritual practice that helps us see the world correctly, as a "cosmic Whole," and thereby orient ourselves properly within it (86). Similarly, many different religious traditions, both ancient and modern, also commend contemplative practices that cultivate attention and focused awareness. So there can be little dispute about the general claim that developing one's powers of attention can be a spiritual practice.

${ }^{13}$ See, for example, Etienne Gilson's study of “Christian Socratism” (1936, chap. 11). 
Given that this general claim is beyond dispute, and given that it is also beyond dispute that analytic theology requires considerable attention and concentration, my path seems clear. I see no reason to deny that one can intentionally practice analytic theology in order to cultivate those exact virtues. Weil and Hadot are both held in very high regard by many contemporary theologians. Presumably, theologians who are happy to agree that geometry (Weil) and stoic metaphysics (Hadot) can function as spiritual exercises should be similarly inclined to say the same thing about intricate analytic proofs and metaphysical arguments.

\subsection{Transparency}

I turn next to what may be regarded as the paradigmatic analytic virtue: argumentative transparency. The culture of analytic philosophy is a culture of argument, and so is the analytic theology that springs from it. I freely grant that the argument culture of analytic philosophy often seems to instantiate a form of pride, or even something that might be called intellectual violence: glory in defeating an opponent in argument, and the queerly intellectualized form of self-love that results. So there is a temptation here, but pride is a perennial temptation-a danger for all forms of human activity.

Hidden within the argument culture of analytic philosophy, however, one finds something that also looks like an inoculation against intellectual pride. Consider the stereotypical form of analytic argumentation: explicit propositional claims, clearly laid out as step-wise arguments, often presented in deductive form. Once one understands how to read analytic philosophy, which does take some getting used to, it is usually exceedingly easy to grasp the claims an author wants to make and the reasons he or she offers in support of those claims. In sum: good analytic writing exhibits the virtue of argumentative transparency. (This is my own, less tendentious rendering of the analytic claim to be especially "clear.")

But this means that part of what it is to offer a good analytic argument is to make that argument maximally easy for intellectual opponents to criticize or refute. This is actually a way of choosing to make oneself intellectually vulnerable, and a check against intellectual pride. In the proper spirit, it is a way of implicitly saying to the intellectual community "If I am wrong, I am wrong in ways that I myself cannot see. Please help me to see them."

Similarly, good analytic philosophy often proceeds very slowly and cautiously, making tiny advances and almost micro-level critiques. This kind of narrow argumentation can sometimes be frustrating for "outsiders" to read, but it can also exhibit real epistemic modesty. One makes the small contribution rather than the grand, totalizing claim, and so one is less tempted to regard oneself as the source of any kind of essential wisdom. Here I am reminded of another excellent quotation from Weil. She writes: "It is perhaps even more useful to contemplate our stupidity than our sin. Consciousness of sin gives us the feeling that we are evil, and a kind of pride sometimes finds a place in it. When we force ourselves to fix the gaze upon a school exercise in which we have failed through sheer stupidity, a sense of our mediocrity is borne in upon us with irresistible evidence. No knowledge is more 
to be desired" (Weil, 1951, 109). It does not seem farfetched to me to say that good analytic philosophy-and therefore good analytic theology-makes it especially easy to have this kind of experience. Even the most successful philosopher is so often shown by his peers to have missed some obvious error that he might be considered a spiritual athlete of stupidity, in Weil's terms.

Once again, someone might well object that all good academic writing aims at argumentative transparency, and so it is not a virtue of analytic theology in particular. And once again, my reply is similar: I make no invidious contrasts. I am prepared to grant that other forms of inquiry may also be regarded as spiritual practices, especially when they foster the intellectual and moral virtues that I here associate with analytic theology. At the same time, it does not seem like special pleading to say that analytic writing maximizes argumentative transparency, and prizes it above almost every other rhetorical virtue, in a way that goes beyond what we find in other disciplines.

\subsection{Imaginative Identification with One's Opponents}

The third feature of analytic argument that I want to highlight is the ability to identify imaginatively with one's intellectual opponents. While very little presentday philosophy and theology takes the form of an explicit dialogue, much of it does still retain an implicit dialogical structure that serves a similar pedagogical purpose. Almost all good philosophy-indeed almost all good inquiry-proceeds by way of an engagement with real and imagined interlocutors. A good piece of philosophical writing presents the views of one's opponents fairly and in their strongest form. It is not uncommon for a philosopher to try his or her best to make an opponent's argument stronger and better before criticizing it, and in the unlikely event that one finds no good counter-arguments in the literature, the right thing to do is to try to imagine good counter-arguments and present them oneself.

This is an utterly ordinary practice, but it can have profound implications. To do it well, one has to be able to inhabit, at least for a time, not only an alternative point of view, but often a hostile point of view. The more easily one can inhabit the viewpoint of one's intellectual opponents, the better one can argue. By contrast, consider what it would be like to be completely unable to do this: one would be so locked in the certainty that one's own views are correct that one could not even imagine what it would be like for them to be wrong. Surely this is a kind of pride, a glorification of the self and its private projects. Conversely, when one can internalize and inhabit the voices of one's critics, the fixed, prideful self becomes unstable. In order to make this move at all, one must try to free oneself from one's own biases and assumptions in order to see the real force of the arguments. One must put oneself in a "truth-seeking" attitude. As I have argued above, for the Christian, adopting a truth-seeking attitude is a way of loving and honoring God.

\subsection{Passively Waiting for Insight}

I conclude with an aspect of analytic philosophy, and therefore analytic theology, that is quite common, even though it is rarely discussed in print. 
Frequently, a philosopher working on a tricky problem experiences a sudden flash of insight, an "ah ha" moment. Such moments seem to strike unexpectedly from "outside," as it were. They do not seem like a predictable result of one's own willful efforts. I am sure these flashes of insight are found in all kinds of intellectual inquiry-indeed, they are part of what makes the intellectual life so pleasurablebut more than most disciplines, successful analytic philosophy must cultivate such these spontaneous experiences of insight. A philosopher must adopt an attitude of patient openness toward the truth, because that attitude is a necessary condition of doing good philosophy. It is an attitude that both presupposes and cultivates intellectual humility. A philosopher who is overly enamored with his own argument, and with himself for having devised it, blocks himself from such moments of insight. Successful analytic philosophy, and therefore successful analytic theology, requires us to cultivate an attitude of "active waiting." We wait for insight, remain open to the truth and patiently hope to receive it, but we wait actively, expectantly. Contrary to stereotypes, the philosopher does not merely lie on the couch looking at the ceiling or spend all day watching television while "waiting" for the truth; rather, he or she reads, thinks, turns ideas over in his or her mind: this is hard work, to be sure, but it is also a form of waiting, and a form of passivity.

It seems to me that this attitude of active waiting is especially valuable for the Christian to cultivate. We spend much of our lives, maybe all of our lives, actively waiting: for God, for grace, for Christ. On some construals, active waiting just is the Christian vocation. When we actively wait for philosophical insight, we participate in a pedagogical practice that is quasi-sacramental. Waiting for insight and cultivating an attitude of openness toward truth is also a way of training the mind and the will to wait actively for God's grace.

\section{Conclusion}

Analytic theology does not wear its spiritual dimension on its sleeve, but neither does the theology of Anselm or Aquinas. Despite the fact that Anselm moves seamlessly from prayers and mediations to technical philosophical arguments, contemporary readers find it all-too easy to focus on the latter at the expense of the former. It is even more clear that few contemporary readers appreciate the practical and spiritual aspects of Aquinas's Summa. It is very easy-indeed, common - to regard Aquinas's work as utterly devoid of spirituality. Yet according to many of his leading theological interpreters, the Summa is a theoretical treatise that also functions as a set of spiritual exercises. Readers must be taught to see the practical aspects of the Summa. They must similarly be taught to see the practical aspects of analytic theology. The fact that they are not obvious to the casual reader does not mean that they are not there. Analytic theology, like the theology of Anselm and Aquinas, is both theoretical and practical. When undertaken in the right spirit, analytic theology can become a spiritual practice: a way of seeking God, and of training the mind and the will to be open to grace. Moreover, the specific techniques of analytic inquiry both presuppose and cultivate the virtue of humility. 
I have said that analytic theology becomes a spiritual practice "when undertaken in the right spirit." This qualification is important, but it does not really bear the weight of the argument. I mean only to say that the right attitude is a necessary condition for appreciating the spiritual value of any practice whatsoever. One can treat any practice, even first-order religious practices like the Eucharist, in a closed-off way, and thereby ensure that they will seem spiritually barren. One can treat analytic theology in a similarly closed-off way, but one need not so treat it. There are resources within analytic theology that allow one to treat it as a spiritual practice, and even-dare I say it—as a "way of life."14

\section{Bibliography}

Adams, Marilyn McCord. 2004. "Anselm on Faith and Reason." In The Cambridge Companion to Anselm. Edited by Brian Davies and Brian Leftow. Cambridge University Press.

Barth, Karl. 1960. Anselm: Fides Quaerens Intellectum : Anselm's Proof of the Existence of God in the Context of his Theological Scheme. SCM.

Candler Jr., Peter M. 2004. "Reading Immemorially: The Quaestio and the Paragraph in the Summa Theologiae." American Catholic Philosophical Quarterly, 78 (4): 531-557.

Coakley, Sarah. 2013. God, Sexuality, and the Self: An Essay 'On the Trinity.' Cambridge University Press.

Crisp, Oliver, and Rea, Micahael C. 2009. Analytic Theology: New Essays in the Philosophy of Theology. Oxford University Press.

Davies, Brian, ed. 2003. Thomas Aquinas, On Evil. Oxford University Press.

Gilson, Etienne. 1936 (1991). The Spirit of Mediaeval Philosophy. University of Notre Dame Press.

Gutiérrez, Gustavo. 1973. A Theology of Liberation. Orbis.

Hadot, Pierre. 1995. Philosophy as a Way of Life: Spiritual Exercises from Socrates to Foucault. Wiley.

\footnotetext{
${ }^{14}$ The paper developed out of a larger project on analytic theology and the academic study of religion that has been generously funded by the John Templeton Foundation. I gave the original version of the paper at the University of Oxford's "Theological Wine" society, and I would like to thank those in attendance, especially Peter Groves, Teresa Morgan, Brian Leftow, Terry Irwin, and John Perry.
} 
Hankey, Wayne J. 2003. "Philosophy as Way of Life for Christians? Iamblichan and Porphyrian Reflections on Religion, Virtue, and Philosophy in Thomas Aquinas." Laval théologique et philosophique 59 (2): 193-224.

Jordan, Mark D. 2006. Rewritten Theology: Aquinas After His Readers. Blackwell.

Leftow, Brian. 1997. "Anselm on the Cost of Salvation." Medieval Philosophy and Theology 6: 73-92.

Marshall, Bruce. 2005. "Quod Scit Unda Uetula: Aquinas on the Nature of Theology." In Rik Van Nieuwenhove and Joseph Peter Wawrykow, eds. The Theology of Thomas Aquinas. University of Notre Dame Press.

Milbank, John. 2009. The Future of Love: Essays in Political Theology. SCM.

Oliver, Simon. 2010. "Analytic Theology." International Journal for Systematic Theology 12 (4): 464-475.

Torrell, J.P. 2003. Thomas Aquinas Volume 2: Spiritual Master. Catholic University of America Press.

- - . 2011. Christ and Spirituality in St. Thomas Aquinas. Catholic University of America Press.

Vanhoozer, Kevin J., ed., 2003. Cambridge Companion to Postmodern Theology. Cambridge University Press.

Williams, Thomas, ed. and trans. 2007. Anselm: Basic Writings. Hackett.

Weil, Simone. 1951. Waiting for God. Harper and Row.

Wood, William. 2013. "Thomas Aquinas on the Claim that God is Truth." Journal of the History of Philosophy 51: 21-47. 